\title{
Comparative analysis of taxation in 8 ex-communist countries in Europe
}

\author{
Razvan Catalin Dobrea ${ }^{1}$, Maria Loredana Popescu ${ }^{1}$, Stefania Cristina Curea ${ }^{1}$, and Victor \\ Marian Dumitrache ${ }^{2 *}$ \\ ${ }^{1}$ Bucharest University of Economic Studies, Piata Romana nr. 6, 010374, Bucharest, Romania \\ ${ }^{2}$ Bucharest University of Economic Studies, PhD student, Piata Romana nr. 6, 010374, Bucharest, \\ Romania
}

\begin{abstract}
Research background: Having a similar background before the 1990, the ex-communist countries in Europe started to differentiate one from another in terms of social and economic development. Nowadays, in many aspects of the socio-economic environment, the differences between them are significant. There are many factors to be considered when analysing the patterns of evolution of each ex-communist country in Europe and one of them is taxation. The level of taxation can lead to structural changes in the economy, especially market economies that are not mature.

Purpose of the article: The purpose of this article is to compare the level of taxation in 8 EU ex-communist countries: Bulgaria, Croatia, Czech Republic, Hungary, Romania, Poland, Slovakia, and Slovenia - in the context of globalization.

Methods: We will do a comparative analysis of the indicators developed by European Commission, DG Taxation and Customs Union and Eurostat of the $8 \mathrm{EU}$ ex-communist countries.

Findings \& Value added: This paper may add value to the economic and tax policies in the $8 \mathrm{EU}$ ex-communist countries by identifying the policies that proved their effectiveness in generating higher labor productivity, policies that can be adapted and then adopted by the UE ex-communist countries that are less developed. Moreover, this paper can lead to more indepth research concerning taxation as significant factor of development in these countries.
\end{abstract}

Keywords: taxation; ex-communist countries in Europe; economic development

JEL Classification: $H 21 ; H 71$

\footnotetext{
${ }^{*}$ Corresponding author : victor.dumitrache@gmail.com
} 


\section{Introduction}

In the research fields of economic development, globalization and fiscal policy, the case of ex-communist countries in Europe can be considered a very good research playground. In the past 30 years, the economies and the political systems of these countries had to adapt and become competitive in a global, interconnected and very dynamic economy. Relative to the other EU countries, the poor economic performance of the ex-communist countries talks about a gap that is still to be bridged and about a transition that has not finished yet (Profiroiu et al., 2020).

After 1990, the market economy and globalization started to influence the fiscal policy of the ex-communist European countries and, the fiscal policies that they adopted has had an impact on their place in the global economy (Bran et al., 2020). Democracy resulted in economic growth (Harun et al., 2020).

As a bases for further research, this article aims to make a comparative analysis of taxation in 8 ex-communist EU countries: Bulgaria, Croatia, Czech Republic, Hungary, Romania, Poland, Slovakia, and Slovenia, in the context of globalization.

In 1999, Schulze and Ursprung synthetized the academic debate on globalization and fiscal policy reducing it to two effects: the efficiency effect and the compensation effect. The efficiency effect refers to the fact that, in the context of market economy and especially within the EU borders (Jha and Gozgor, 2019), the free move of goods and capitals makes the countries to lower the taxes thereby lowering their ability to provide public goods (Radulescu et al., 2020). The compensation effect refers to the fact that the fee move of persons and migration may increase the demand for social insurance programs therefore increasing inequality and volatility (Profiroiu et al., 2019).

According to Romer and Romer (2010), it is hard to precisely measure the changes in real GDP or in specific components of it, like investment or consumption, caused by tax changes. Some taxes are reactive to economic growth and analyzing tax cuts at a certain point in time, without the entire context, may lead to wrong conclusions. Moreover, it is hard to isolate tax changes from other variables that have an impact on economic growth.

However, there is a strong and coherent body of evidence showing the effects of taxation on economic growth. Analyzing time series from 1946 to 2012, Mertens and Olea (2018) found that marginal rate cuts led to both increases in real GDP and declines in unemployment. More specific, they found that decreasing the tax rate by 1 percent-point, increases the real GDP by $0.78 \%$ in the $3^{\text {rd }}$ year after the tax change.

There are evidence showing that tax increases do not support the economic growth, while tax cuts generate a positive outcome especially in periods of recession (Negescu Oancea, et al., 2020). Ljungvist and Smolyansky (2018) found that decreasing the corporate tax rates by 1 percent-point leads employment to raise by $0.2 \%$ and wages by $0.3 \%$. This conclusion is based on data serios analysis of 250 state corporate tax changes from 1970 to 2010.

In another study, Nguyen et al (2021) demonstrated that in the UK, a percentage-point decrease in the average income tax rate raises GDP by 0.78 percent. They used time series of individual income, corporate, and consumption taxes from 1973 to 2009.

Gunter et al. (2019) showed that the effect of taxes on growth are highly non-linear. When the tax rate is low, tax changes generate almost no impact, but when the tax rate is high, the tax changes create significant impact. They analyzed VAT variations of 51 countries from 1970 to 2014. At specific tax rates, further increases beyond that rate will actually reduce tax revenues. In the case of European heavily industrialized and digitalized countries, the tax multiplier estimate is $\mathbf{- 3 . 6}$ for two years after a tax change. This demonstrates that tax cuts significantly stimulate economic growth and activity in these countries, including innovation. 


\section{Methods}

The purpose of this article is to compare the level of taxation in $8 \mathrm{EU}$ ex-communist countries: Bulgaria, Croatia, Czech Republic, Hungary, Romania, Poland, Slovakia, and Slovenia - in the context of globalization.

Table 1. The 8 EU ex-communist countries sorted by GDP/capita in 2019 .

\begin{tabular}{|c|c|c|}
\hline Country & GDP/Capita 2019, PPP\$ & GDP/Capita 1997, PPP\$ \\
\hline Czech Republic & 37370.97 & 14727.91 \\
\hline Slovenia & 36745.89 & 15277.65 \\
\hline Slovakia & 35129.79 & 10082.63 \\
\hline Poland & 31938.66 & 8920.16 \\
\hline Hungary & 31902.67 & 9821.53 \\
\hline Romania & 26446.74 & 5562.19 \\
\hline Croatia & 26221.43 & 9461.58 \\
\hline Bulgaria & 23155.64 & 5748.48 \\
\hline
\end{tabular}

Source: Bran (2020)

The economic growth of these $8 \mathrm{EU}$ ex-communist countries may be sensitive to tax variations. Taking only the VAT into consideration, according to Gunter et al. (2019), increases in the VAT in countries with high VAT rates, such as much of industrialized Europe, will have more significant impacts on GDP than increases in countries with low VAT rates.

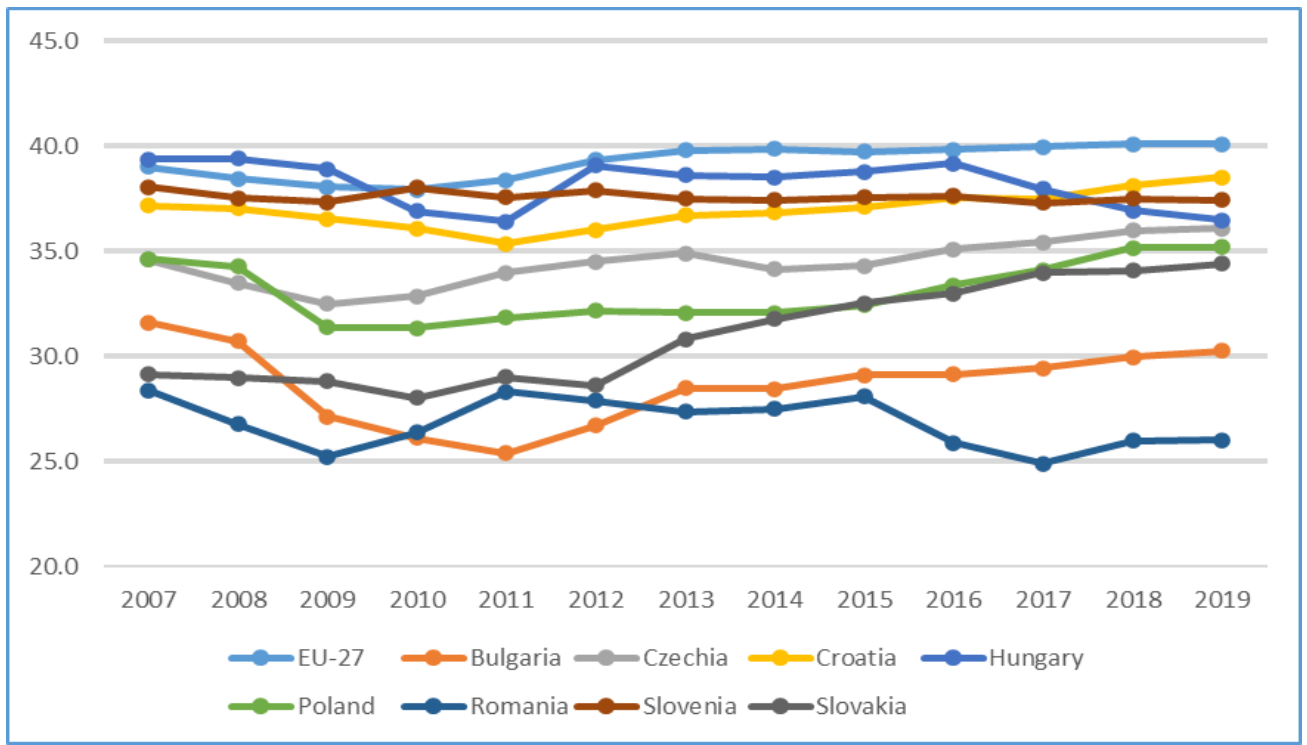

Figure 1. Total taxes (including compulsory actual social contributions) as \% of GDP. 
In figure 1 we can see that, relative to their GDP, Slovakia, Czech Republic and Poland increased their tax revenues between 2007 to 2019, bridging the gap to Slovenia, Hungary and Croatia that had a constant level of revenues in this period. These 6 countries are clustered together in the $34.4 \%$ - 38.5\% range, while Romania (26\%) and Bulgaria (30.3) are far below.

Table 1 reflects the same situation, but from the perspective of GDP/capita. Same as in total taxes share in GDP, Romania and Bulgaria have the lowest GDP/capita. This fact triggers a lot of other economic and social issues as these countries have a lower capacity to provide public goods at the same level, quantity or quality comparing to other EU countries.

Following the purpose of this paper, we used the comparative analysis method. We chose several indicators that can give us a broader image on fiscal policy in the $8 \mathrm{EU}$ ex-communist countries:

a) Distribution of tax revenues according to type of tax base $2019, \%$ of total taxes

b) Share of indirect taxes in total tax revenues (\%)

c) Share of direct taxes in total tax revenues (\%)

d) Share of social tax contribution in total tax revenues (\%)

For all of these indicators we used data from 2019. The data sources are: European Commission, DG Taxation and Customs Union and Eurostat.

\section{Results and Discussion}

\subsection{Findings}

Figure 2 shows the distribution of tax revenues according to type of tax, as percentage of total taxes. We can observe that countries with the highest share of consumption taxes are Croatia (50.9\%) and Bulgaria (47.2\%), far above the EU-27 average (27.8\%) These are also the countries with the lowest GDP/capita in 2019. According to Gunter et al. (2019), consumption tax cuts would strongly stimulate economic activity in these countries.

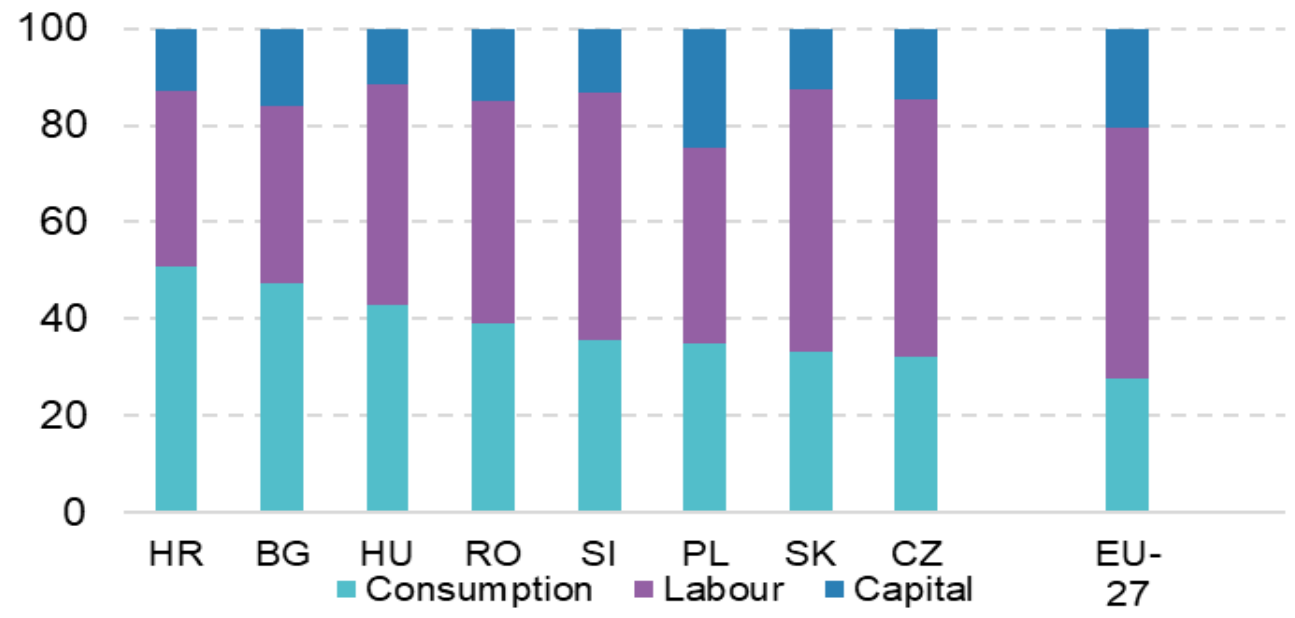

Figure 2. Distribution of tax revenues according to type of tax base $2019, \%$ of total taxes.

Source: European Commission, DG Taxation and Customs Union

Also, we can observe that all 8 ex-communist EU countries have above EU-27 average consumption tax rates indicating policies that support the development of private sector, with lower labor and capital taxes. 


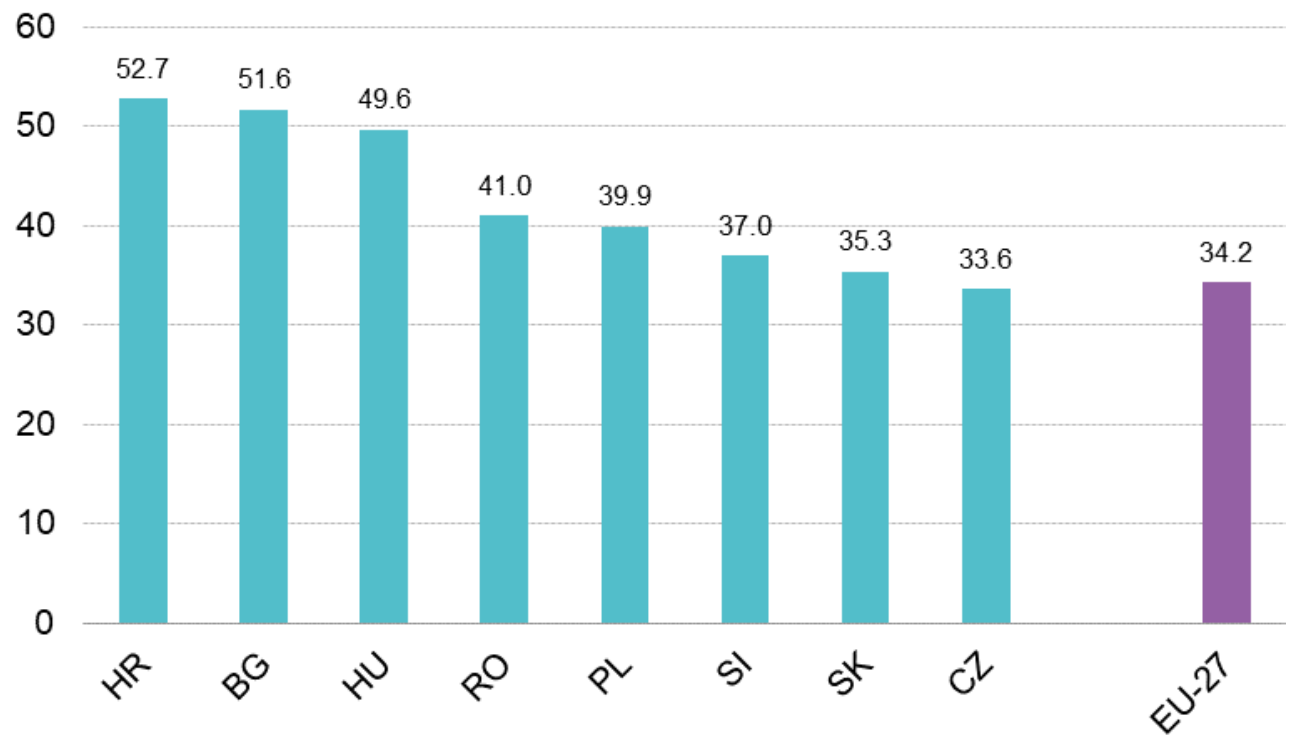

Figure 3. Share of indirect taxes in total tax revenues (\%) in 2019.

Source: Eurostat (online data code: gov_10a_taxag)

The share of indirect taxes in total tax revenues in 2019 (table 3) reflects the high percentage of consumption taxes in the 8 ex-communist EU countries. Excepting Czech Republic, the other 7 are all above the EU average of 34.2\% indirect taxes in total taxes. Any tax rate increases (live VAT or excise duties on fuel) will generate the opposite effect especially in Croatia, Bulgaria, and Hungary, generating less tax revenues, as the tax rates are already high.

Based on the share of indirect taxes in total tax revenues, the 8 countries form 2 clusters, as following: 1) Croatia, Bulgaria, Hungary and Romania with shares ranging between $41 \%$ (Romania) to $52.7 \%$ (Croatia). 2) Poland, Slovenia, Slovakia, Czech Republic with shares ranging from $39.9 \%$ (Poland) to 33.6\% (Czech Republic). 


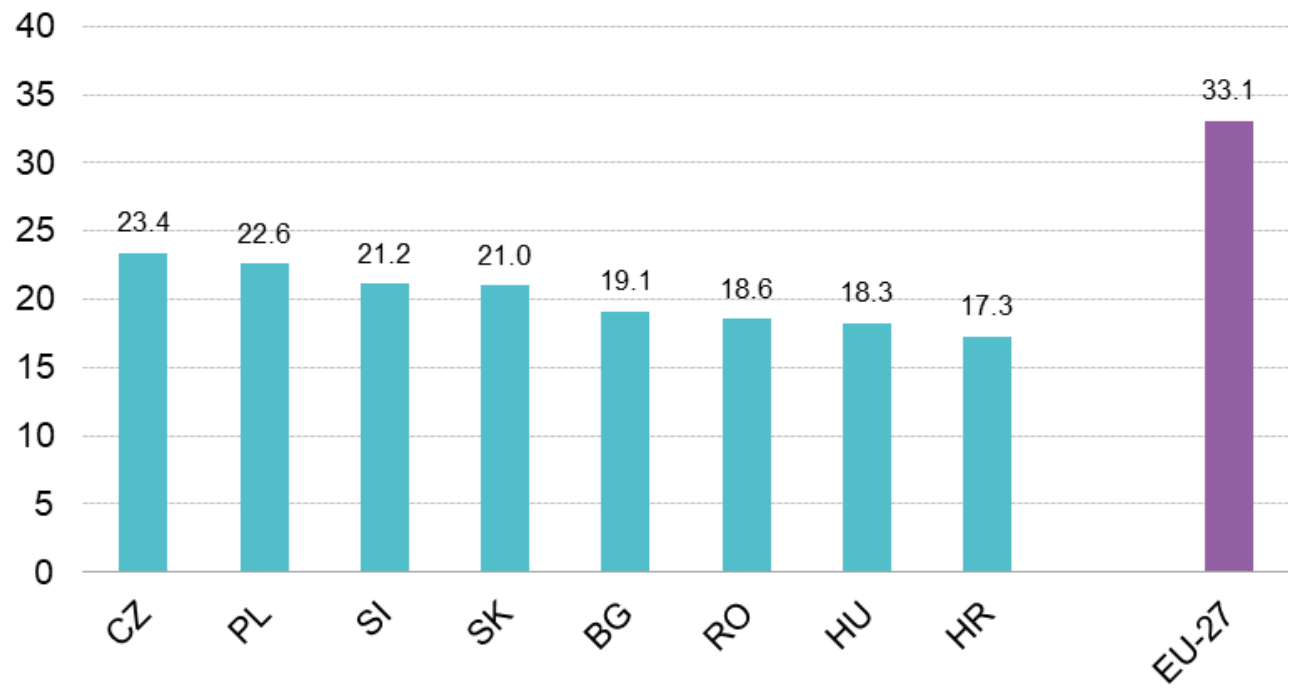

Figure 4. Share of direct taxes in total tax revenues (\%) in 2019.

Source: Eurostat (online data code: gov_10a_taxag)

The share of direct taxes in total tax revenues in 2019 (figure 4) shows us that the excommunist countries in the EU are significantly below the EU-28 average. It means that in these countries are in force the lowest income taxes, property taxes, and taxes on asset at EU level.

Based on this criterion, all the 8 countries form together one cluster, having shares ranging from $23.4 \%$ (Czech Republic) to $17.3 \%$ (Croatia). All countries are well below the EU-27 average of $331 \%$. This may have deep roots in communism when the concept of private property was almost nonexistent.

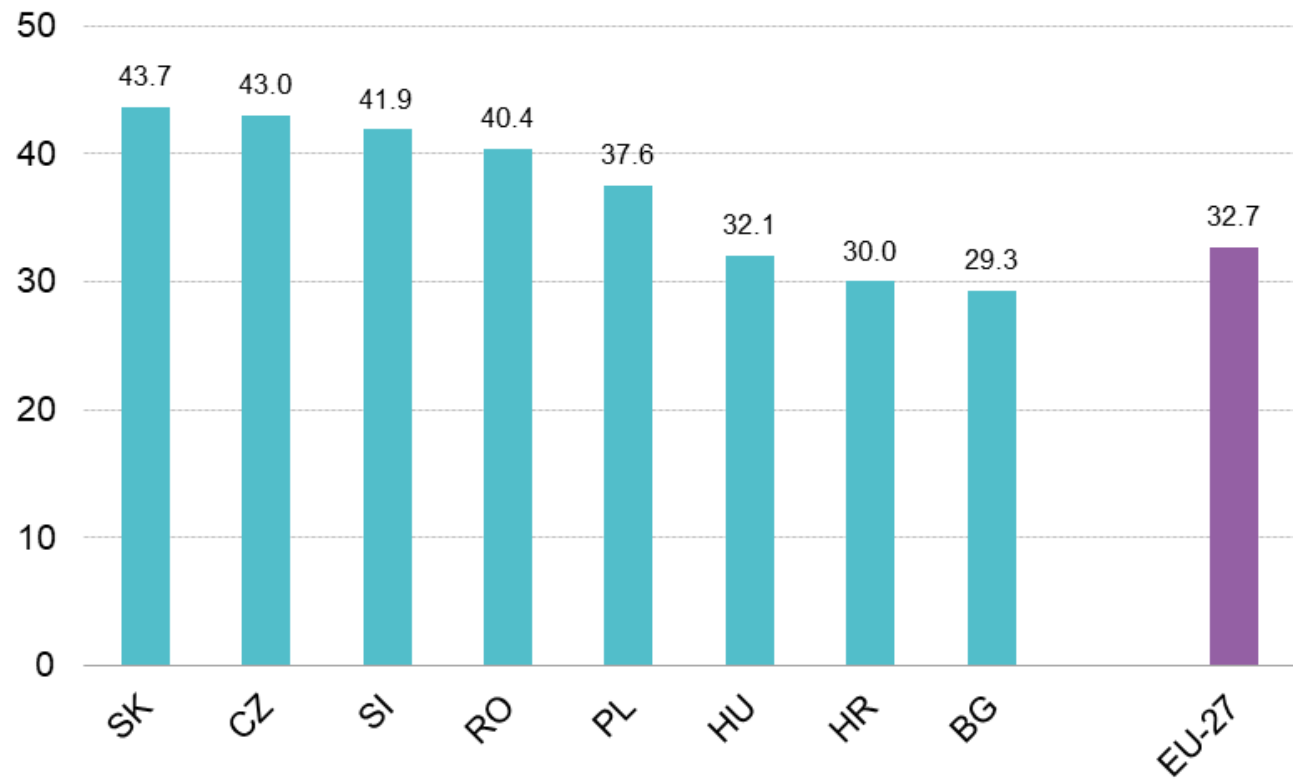


Figure 5. Share of social tax contribution in total tax revenues (\%) in 2019.

Source: Eurostat (online data code: gov_10a_taxag)

The share of social tax contribution in total tax revenues (figure 4) is above the EU-28 average in 5 of the 8 ex-communist EU countries: Slovakia, Czech Republic, Slovenia, Romania, and Poland. This can be explained through the appetence of the ex-socialist states to deliver as many social and health services as possible in economies with no alternatives to the state system, especially in the ' 90 s and early 2000.

Also, EU has a highly competitive labor market due to its higher education capabilities, training the top professionals worldwide (Dumitrache et al., 2020). This comes with high wages and with high revenues from the social taxes.

\section{Conclusion}

In this article we compared the level of taxation in 8 UE ex-communist countries: Bulgaria, Croatia, Czech Republic, Hungary, Romania, Poland, Slovakia, and Slovenia. Even if these countries have similar backgrounds before '90s, their fiscal policies became a significant differentiator among them after '90s.

Among the EU countries, even heterogenous, the 8 ex-communist countries are all above average in consumption taxes and below average in labor taxes. Even if they have low \% of total taxes in GDP, increasing the consumption taxes would not bring more tax revenues, as these taxes are already one of the highest in EU. Also, increasing the labor taxes may not bring additional revenues, as these countries have strong informal labor market that may get even bigger by increasing the labor taxes.

Comparing these countries by different types of tax revenues, we observed that they all have in common a similar share of direct taxes in total taxes, ranging from $23.4 \%$ in Czech Republic to $17.3 \%$ in Croatia. These are all below the EU average, these countries having the lowest income taxes, property taxes, and taxes on asset at EU level.

Comparing the social tax contribution share in total taxes, we can see that the 8 countries have different policies. 3 of them are below the EU average, and 5 are above average. We can consider that health and social security public systems from these countries are already under high pressure due to the high migration rate to western EU countries, on one hand, and to aging of the active population, on the other hand. For these reasons, we can expect further increases of the social tax rates in the following years.

The main limitation of this paper is that all the data used for the comparative analysis are from before the pandemic crisis, so we cannot tell if the health crisis has already influenced the tax policies from these countries.

\section{References}

1. Bran, F., Rădulescu, C. V., Bodislav, D. A., \& Burlacu, S. (2020). Environmental risks in the context of globalization. Economic Convergence in European Union, 350.

2. Burlacu, S., Diaconu, A., Balu, E. P., \& Gole, I. (2021). The economic and social effects of unemployment in Romania. Revista de Management Comparat International, 22(1), 21-27.

3. Harun, R., Warsame, H., \& Khan, S. (2020). The differential impact of democracy on tax revenues in developing and developed countries. International Journal of Public Administration, 44, 623-635.

4. Jha, P., \& Gozgor, G. (2019). Globalization and taxation: Theory and evidence. European Journal of Political Economy, 59, 296-315. 
5. Mertens, K., \& Olea, J. L. M. (2018). Marginal tax rates and income: New time series evidence. The Quarterly Journal of Economics, 133(4), 1803-1884.

6. Nguyen, Anh D. M., Onnis, L., \& Rossi, R. (2021). The macroeconomic effects of income and consumption tax changes. American Economic Journal: Economic Policy, 13(2), 439-466.

7. Profiroiu, A., Burlacu, S., \& Sabie, O. (2019). Reform of the pension system in Romania. Calitatea, 20(S2), 521-524.

8. Profiroiu, M. C., Radulescu, C. V., Burlacu, S., \& Guţu, C. (2020). Changes and trends in the development of the world economy. In Competitivitatea şi Inovarea în Economia Cunoaşterii, (pp. 324-330).

9. Rădulescu, C. V., Burlacu, S., Bodislav, D. A., \& Bran, F. (2020). Entrepreneurial education in the context of the imperative development of sustainable business. European Journal of Sustainable Development, 9(4), 93-93.

10. Romer, C. D., \& Romer, D. H. (2010). The macroeconomic effects of tax changes: estimates based on a new measure of fiscal shocks. American Economic Review.

11. Schulze, H.W. Ursprung globalisation of the economy and the nation state. World Economy, 22(3), 295-352.

12. Ljungqvist, A., \& Smolyansky, M. (2018). To cut or not to cut? On the impact of corporate taxes on employment and income. National Bureau of Economic Research.

13. Gunter, S., Riera-Crichton, D., Vegh C., \& Vuletin G. (2019). Non-linear effects of tax changes on output: The role of the initial level of taxation. National Bureau of Economic Research.

14. Bran, F., Niculescu, M. A., Dumitrache V. M., \& Gombos S. P. (2020). The dynamics of innovation in the ex-communist countries in Europe in the context of globalization. The 20th International Scientific Conference Globalization and its Socio-Economic Consequences 2020.

15. Dumitrache, V. M., Gombos, S. P., Bran, F., \& Balu, E. B. (2020). The dynamics of human capital accumulation in the ex-communist countries in Europe in the context of globalization, The 20th International Scientific Conference Globalization and its SocioEconomic Consequences 2020.

16. Negescu, M. D., Burlacu, S., Mitriţă, M., \& Buzoianu, O. C. A. (2020). Managerial analysis of factoring at the international level. Challenges of the Contemporary Society, 13(1), 99-102. 